\title{
Aerobic addition of secondary phosphine oxides to vinyl sulfides: a shortcut to 1-hydroxy-2-(organosulfanyl)ethyl- (diorganyl)phosphine oxides
}

\author{
Svetlana F. Malysheva ${ }^{1}$, Alexander V. Artem'ev ${ }^{1}$, Nina K. Gusarova ${ }^{1}$, \\ Nataliya A. Belogorlova ${ }^{1}$, Alexander I. Albanov ${ }^{1}$, C. W. Liu ${ }^{2}$ and Boris A. Trofimov ${ }^{* 1}$
}

Address:

${ }^{1}$ A. E. Favorsky Irkutsk Institute of Chemistry, Siberian Branch,

Russian Academy of Sciences, 1 Favorsky Str., 664033 Irkutsk,

Russian Federation and ${ }^{2}$ Department of Chemistry, National Dong

Hwa University, Hualien 97401, Taiwan

Email:

Boris A. Trofimov ${ }^{*}$ - boris_trofimov@irioch.irk.ru

${ }^{*}$ Corresponding author

Keywords:

addition; green method; phosphine oxides; regioselectivity; vinyl

sulfides

\author{
Beilstein J. Org. Chem. 2015, 11, 1985-1990. \\ doi:10.3762/bjoc.11.214 \\ Received: 20 May 2015 \\ Accepted: 21 September 2015 \\ Published: 23 October 2015 \\ Associate Editor: P. R. Hanson \\ (c) 2015 Malysheva et al; licensee Beilstein-Institut. \\ License and terms: see end of document.
}

\section{Abstract}

Secondary phosphine oxides react with vinyl sulfides (both alkyl- and aryl-substituted sulfides) under aerobic and solvent-free conditions $\left(80^{\circ} \mathrm{C}\right.$, air, 7-30 h) to afford 1-hydroxy-2-(organosulfanyl)ethyl(diorganyl)phosphine oxides in 70-93\% yields.

\section{Findings}

Tertiary phosphines and phosphine chalcogenides are important organophosphorus compounds that are widely used in industry, organic synthesis, polymer science, medicinal and coordination chemistry [1-4]. Therefore, the synthesis of these compounds has attracted a great interest and numerous synthetic methods have been developed [5-7]. Among them, the addition of $\mathrm{P}(\mathrm{X})-\mathrm{H}(\mathrm{X}=$ none, $\mathrm{O}, \mathrm{S}$ or $\mathrm{Se})$ to diverse alkenes is one of the most powerful and $100 \%$ atom-economic approaches to construct new $\mathrm{C}-\mathrm{P}$ bonds, that provide straightforward access to tertiary phosphines and their chalcogenides [8-12]. Conventionally, the activation of the $\mathrm{P}-\mathrm{H}$ bonds in this reaction is achieved by using radical initiators [13-15], Brønsted/Lewis acids [16,17] and bases [18-20] as well as transition metal catalysts [21-23]. Also, examples of the microwave-assisted [24,25] and photoinduced [26] addition are described.

Recently, on example of secondary phosphines [27] as well as secondary phosphine sulfides [28] and selenides [29], it has been disclosed that the addition of $\mathrm{P}-\mathrm{H}$ species to the $\mathrm{C}=\mathrm{C}$ bonds readily proceeds in the absence of any catalyst or initiator (Scheme 1). The reactions occur under mild solvent-free conditions $\left(70-80{ }^{\circ} \mathrm{C}\right.$, inert atmosphere, $\left.3-15 \mathrm{~h}\right)$ to chemo- and 
regioselectively furnish the anti-Markovnikov adducts in excellent yields (up to 99\%). The substrate scope includes both EDG- and EWG-substituted alkenes [27-29].<smiles>[R]C=C[CH-][Y]([R])([R])[H]</smiles>

$\mathrm{X}=$ none, $\mathrm{S}$ or $\mathrm{Se}$; $\mathrm{R}=$ alkyl, aryl, etc. $\mathrm{R}^{\prime}=\mathrm{EWG}, \mathrm{EDG}$

Scheme 1: Non-catalyzed addition of $\mathrm{P}-\mathrm{H}$ species to alkenes
In this letter, we report our serendipitous finding that secondary phosphine oxides $\mathbf{1 a}-\mathbf{f}$ under aerobic conditions (air, $80{ }^{\circ} \mathrm{C}$, 7-18 h) easily add to vinyl sulfides $\mathbf{2 a}-\mathbf{c}$ to give unknown 1-hydroxy-2-(organosulfanyl)ethyl(diorganyl)phosphine oxides 3a-h in high yields (Table 1). The $10 \%$ excess of $\mathbf{2 a - c}$ relative to $1 \mathbf{a}-\mathbf{f}$ is found to be optimal since the equimolar ratio of the reactants leads to incomplete conversion of the secondary phosphine oxides.

Importantly, under these conditions, the expected [30] antiMarkovnikov adducts are not observed in detectable amounts $\left({ }^{31} \mathrm{P} \mathrm{NMR}\right)$. The main byproducts are phosphinic acids, $\mathrm{R}_{2} \mathrm{P}(\mathrm{O}) \mathrm{OH}$, formed by air oxidation of secondary phosphine oxides 1a-f. As seen from Table 1, the reaction is applicable to

Table 1: The substrate scope for the aerobic addition of phosphine oxides $1 a-f$ to vinyl sulfides $2 a-c .^{a}$

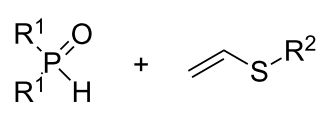

1a-f
西

air

$80^{\circ} \mathrm{C}, 7-30 \mathrm{~h}$

$2 a-c$<smiles>[R][SH]CC(O)P([R])([R])=O</smiles>

3a-h (70-93\%)

Entry Phosphine oxide

1a

2<smiles>C[PH](=O)CCc1ccccc1CCc1ccccc1</smiles>

$1 a$

$\mathrm{Ph}_{2} \mathrm{P}(\mathrm{O}) \mathrm{H}$

$1 \mathrm{~b}$<smiles>C=CS[AsH2]C(C)(C)C</smiles>

2a<smiles>C=CSOCCCCCCCC</smiles>

$2 b$<smiles>C=CSc1ccccc1</smiles>

16

Time, $\mathrm{h}$
Phosphine oxide $3 \mathbf{a}-\mathbf{h}($ yield, \%)
3

4<smiles>C[PH](=O)CCCc1ccccc1</smiles>

1a<smiles>CC(C)(C)SCC(O)P(=O)(CCc1ccccc1)CCc1ccccc1</smiles>

3a $(80 \%)$<smiles>[14CH3]SCC(O)P(=O)(CCc1ccccc1)CCc1ccccc1</smiles>

3b $(78 \%)$<smiles>O=P(c1ccccc1)(c1ccccc1)C(O)CSc1ccccc1</smiles>

3c $(70 \%)$<smiles>O=P(CCc1ccccc1)(CCc1ccccc1)C(O)CSc1ccccc1</smiles>

3d (91\%) 
Table 1: The substrate scope for the aerobic addition of phosphine oxides $1 \mathrm{a}-\mathrm{f}$ to vinyl sulfides $2 \mathrm{a}-\mathrm{c}^{\text {a }}{ }^{\text {(continued) }}$

5<smiles>Cc1ccc(CCPP(C)(=O)CCc2ccc(C)cc2)cc1</smiles>

6<smiles></smiles>

1d

7<smiles>[2H][PH](=O)CCc1ccc(Cl)cc1</smiles>

8

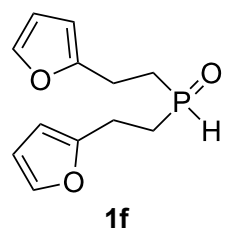

15<smiles>Cc1ccc(CCP(=O)(CCc2ccc(C)cc2)C(O)CSc2ccccc2)cc1</smiles>

3e $(93 \%)$<smiles>C=CSc1ccccc1</smiles>

15<smiles>CC(C)(C)c1ccc(CCP(=O)(CCc2ccc(C(C)(C)C)cc2)C(O)CSc2ccccc2)cc1</smiles>

3f $(90 \%)$<smiles>C=CSc1ccccc1</smiles>

18<smiles>O=P(CCc1ccc(Cl)cc1)(CCc1ccc(Cl)cc1)C(O)CSc1ccccc1</smiles>

3 g $(82 \%)$

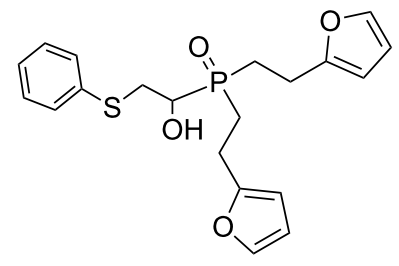

3h (89\%)

aReaction conditions: secondary phosphine oxide $1 \mathrm{a}-\mathrm{f}(1.0 \mathrm{mmol})$, vinyl sulfide $2 \mathrm{a}-\mathrm{c}(1.1 \mathrm{mmol})$ at $80{ }^{\circ} \mathrm{C}$ for $7-30 \mathrm{~h}$ under air. ${ }^{\mathrm{b}} / \mathrm{solated}$ yield based on 1a-f.

both aryl- (1b) and arylalkyl-substituted $(\mathbf{1} \mathbf{a}, \mathbf{c}-\mathbf{e})$ secondary phosphine oxides. The furyl-containing phosphine oxide $\mathbf{1 f}$ can also be reacted under these reaction conditions. On the other hand, vinyl sulfides bearing alkyl (2a,b) and aryl (2c) substituents successfully participate in the reaction to provide the corresponding phosphine oxides $\mathbf{3 a}-\mathbf{h}$. The latter were isolated as air- and moisture-stable powders (3a-f) or oils $(\mathbf{3 g}, \mathbf{h})$, soluble in common organic solvents. Their structures have been established by X-ray diffraction (for 3d, Figure 1), NMR $\left({ }^{1} \mathrm{H},{ }^{13} \mathrm{C},{ }^{31} \mathrm{P},{ }^{1} \mathrm{H},{ }^{13} \mathrm{C}\right.$-HSQC $)$ and FTIR techniques.

The presence of an asymmetric carbon atom in the reaction products leads to non-equivalence of both heminal protons in the $\mathrm{SCH}_{2} \mathrm{C}^{*}$ fragment and carbon signals in the arylethyl moiety. In the ${ }^{1} \mathrm{H}$ NMR spectra of $\mathbf{3 a}-\mathbf{h}$, protons of the $\mathrm{PCHCH}_{2} \mathrm{~S}$ moiety form an ABMX spin system appearing as three multiplets.
Phosphine oxide 3d crystallizes in the centrosymmetric $P 2{ }_{1} / c$ space group. Within its extended structure, strong intermolecular H-bonding interactions between the $\mathrm{O}-\mathrm{H}$ hydrogen and $\mathrm{P}=\mathrm{O}$ oxygen atom of a second molecule $\{\mathrm{O}(1)-\mathrm{H}(1) \cdots \mathrm{O}(2)$, 1.80(6) $\AA$; O- $\mathrm{H} \cdots \mathrm{O}$ angle, $174.9(7)^{\circ}$ \} leads to the formation of $1 \mathrm{D}$ polymeric chains along the $b$-axis (Figure S1, Supporting Information File 1).

In FTIR spectra of $\mathbf{3 a}-\mathbf{h}$, absorption bands of the $\mathrm{P}=\mathrm{O}$ and $\mathrm{O}-\mathrm{H}$ bonds appear in the regions of 1100-1150 and $3350-3450 \mathrm{~cm}^{-1}$, respectively.

Interestingly, the reaction disclosed is specific for secondary phosphine oxides. Our experiments have shown that their analogues, secondary phosphine sulfides, under similar conditions provide exclusively the anti-Markovnikov adducts (Scheme 2). On the other hand, vinyl ethers and vinyl selenides 


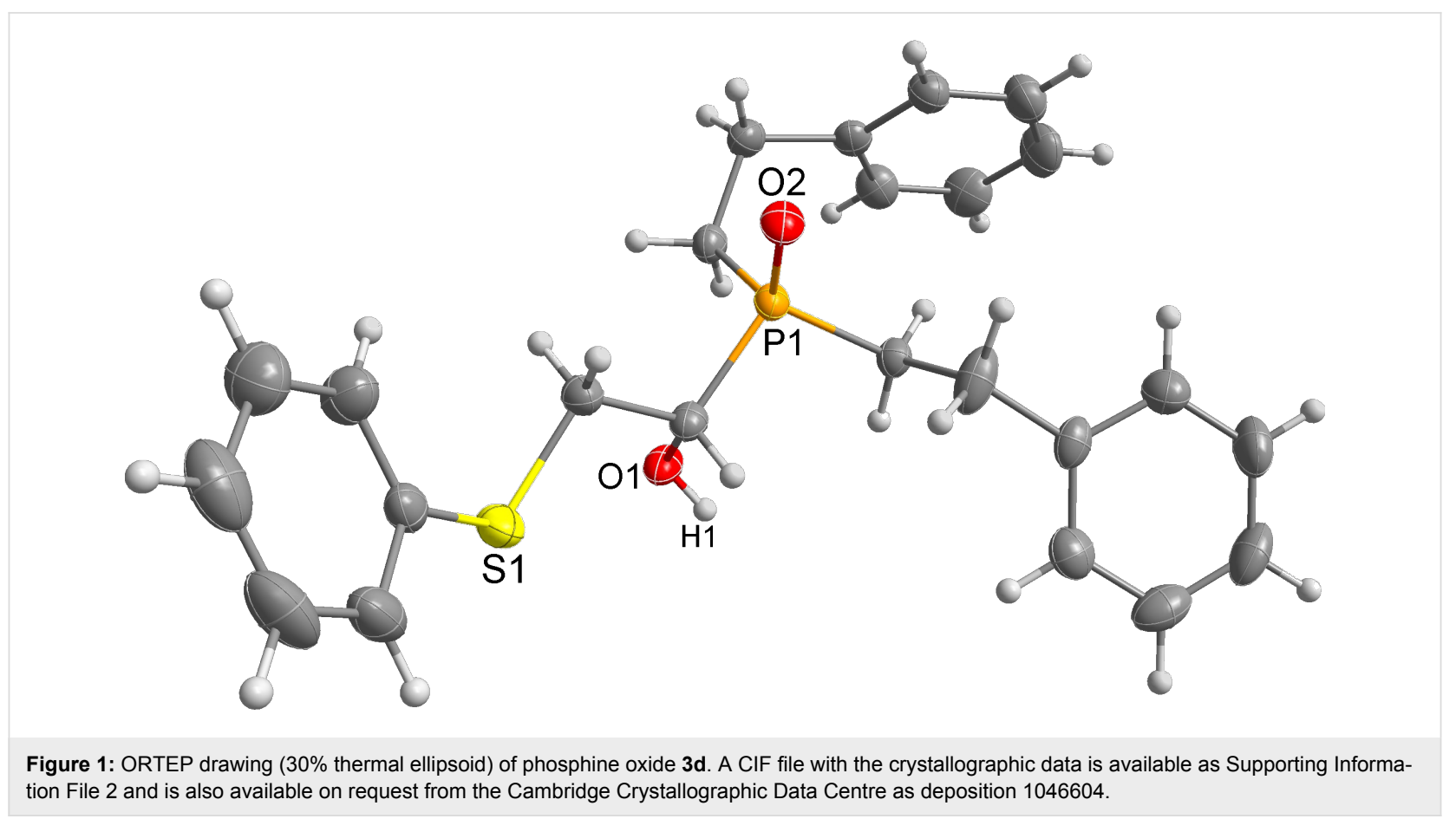

(congeners of vinyl sulfides) were found to react with phosphine oxide $1 \mathrm{a}$ at $80^{\circ} \mathrm{C}$ for about 30 and $20 \mathrm{~h}$, respectively, to deliver difficult-to-separate mixtures of organophosphorus compounds ( $\left.{ }^{31} \mathrm{P} \mathrm{NMR}\right)$.

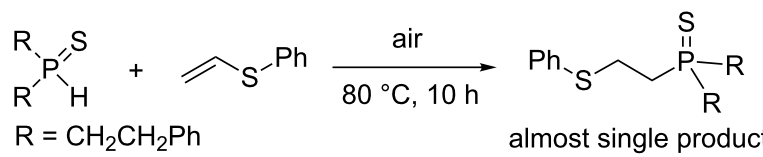

( ${ }^{31} \mathrm{P}$ NMR)

Scheme 2: Addition of secondary phosphine sulfide to vinyl sulfide under aerobic catalyst-free conditions.

To gain a primary insight into the reaction mechanism, several experiments were carried out. On example of phosphine oxide 1a and vinyl sulfide $\mathbf{2 c}$, we have shown that the reaction proceeds in the dark with the same efficiency as in the light. Therefore, the photochemical pathway of the reaction is hardly probable. Also, the reaction was established under an argon atmosphere. Under these conditions (argon, $80^{\circ} \mathrm{C}$ for $18 \mathrm{~h}$, exemplified by $\mathbf{1 a} / \mathbf{2 c}$ pair) the formation of products $\mathbf{3 a}-\mathbf{h}$ does not take place and the starting phosphine oxide remained almost intact $\left({ }^{31} \mathrm{P}\right.$ NMR). This indicates that the reaction requires the presence of oxygen. In the other experiment, when TEMPO, a widely used radical scavenger, was added $(10 \mathrm{~mol} \%)$ into the reaction system $\mathbf{1 a} / \mathbf{2 c}$, the product $\mathbf{3 d}$ was also formed, however, a longer reaction time was required for complete conversion of secondary phosphine oxide 1a as compared to TEMPO-free conditions ( 15 vs $11 \mathrm{~h}$ ). Meanwhile, this observation does not completely exclude a radical mechanism since the cross-coupling reactions between TEMPO and radical intermediates can be reversible [31]. In future, we intend to check various radical scavengers (other than TEMPO) in order to better understand the reaction mechanism.

Taking these data into account, the following mechanism is suggested (Scheme 3). The first step is assumed to be the generation of phosphinoyl (A) and hydroperoxyl (HOO') radicals by the reaction of $\mathrm{O}_{2}$ with phosphine oxide 1. Earlier, the transfer of a hydrogen atom from the $\mathrm{P}(\mathrm{O}) \mathrm{H}$ species to molecular oxygen has been reported for example for $\mathrm{Ph}_{2} \mathrm{P}(\mathrm{O}) \mathrm{H}$ [30]. Then, the radical addition of $\mathbf{A}$ to vinyl sulfide, proceeding in an anti-Markovnikov manner, takes place. Subsequently, a 1,2intramolecular transfer of an $\mathrm{H}$ atom within the radical adduct $\mathbf{B}$ (from $\mathrm{PCH}_{2}$ group to radical center) leads to the formation of $\mathrm{R}_{2} \mathrm{P}(\mathrm{O})$-stabilized radical $\mathrm{C}$. The latter recombines with a hydroperoxide radical to afford the metastable hydroperoxide D, thermal decomposition of which give rise to the final product 3 .

Although quantum chemical computations [MP2/6$311++\mathrm{G}(\mathrm{d}, \mathrm{p}) / / \mathrm{B} 3 \mathrm{LYP} / 6-311++\mathrm{G}(\mathrm{d}, \mathrm{p})]$ of the model radicals $\mathbf{B}$ and $\mathbf{C}$ (with $\mathrm{R}, \mathrm{R}^{\prime}=\mathrm{Me}$ ) reveals that the latter is energetically less preferred than the former, their energy difference is too small $(4.38 \mathrm{kcal} / \mathrm{mol})$ to completely prohibit the $\mathbf{B} \rightarrow \mathbf{C}$ transformation. 


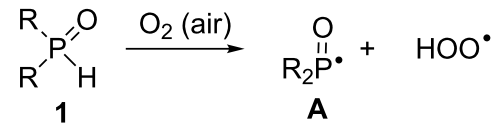

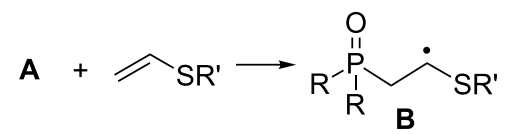

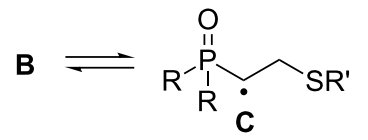

$$
\begin{aligned}
& C+\mathrm{HOO}^{\circ} \longrightarrow \mathrm{R}_{\mathrm{P}}^{\mathrm{R}-\mathrm{POH}^{\prime \prime}} \underbrace{\mathrm{O}}_{\mathrm{SR}^{\prime}}
\end{aligned}
$$

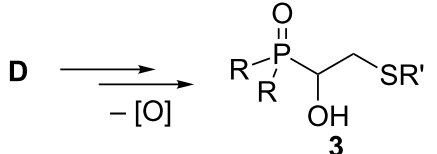

Scheme 3: Putative mechanism.

\section{Conclusion}

In summary, we have disclosed an aerobic addition of secondary phosphine oxides to vinyl sulfides under solvent- and catalyst-free conditions, which provides an efficient approach to hitherto unknown 1-hydroxy-2-(organosulfanyl)ethyl(diorganyl)phosphine oxides in one step. The synthesized phosphine oxides, bearing hydroxy and sulfide functions, represent prospective building blocks for organic synthesis and interesting ligands for metal complexes. The results obtained contribute to the basic chemistry of both phosphine oxides and vinyl sulfides.

\section{Supporting Information}

\section{Supporting Information File 1}

General remarks, experimental procedure and characterization data; crystallographic information for $\mathbf{3 d}$; ${ }^{1} \mathrm{H},{ }^{13} \mathrm{C} \&{ }^{31} \mathrm{P}$ NMR spectra of synthesized compounds. [http://www.beilstein-journals.org/bjoc/content/ supplementary/1860-5397-11-214-S1.pdf]

\section{Supporting Information File 2}

CIF file of compound $\mathbf{3 d}$.

[http://www.beilstein-journals.org/bjoc/content/ supplementary/1860-5397-11-214-S2.cif]

\section{Acknowledgements}

This work was supported by leading scientific schools by the President of the Russian Federation (Grant NSh-156.2014.3).

\section{References}

1. Goldwhite, H. Introduction to Phosphorus Chemistry; Cambridge University Press: Cambridge, 1981.

2. Quin, L. D. A Guide to Organophosphorus Chemistry; John Wiley and Sons: New York, USA, 2000.

3. Peruzzini, M.; Gonsalvi, L. Phosphorus Compounds, Advanced Tools in Catalysis and Materials Science, Catalysis by Metal Complexes; Springer: Dordrecht, 2011. doi:10.1007/978-90-481-3817-3

4. Kamer, P. C. J.; van Leeuwen, P. W. N. M. Phosphorus(III) Ligands in Homogeneous Catalysis: Design and Synthesis; John Wiley and Sons: Chichester, U.K., 2012. doi:10.1002/9781118299715

5. Hartley, F. R. Phosphine Oxides, Sulphides, Selenides and Tellurides; The Chemistry of Organophosphorus Compounds, Vol. 2; John Wiley and Sons: Chichester, U.K., 1992. doi:10.1002/0470034424

6. Engel, R.; Cohen, J. I. Synthesis of carbon-phosphorus bonds, 2nd ed.; CRC Press: Boca Raton, USA, 2004.

7. Kilah, N. L.; Wild, S. B. Product Class 13: Trialkylphosphine Oxides, Sulfides, Selenides, Tellurides, and Imides. In Science of Synthesis; Mathey, F., Ed.; Georg Thieme Verlag: Stuttgart, Deutschland, 2009; Vol. 42, pp 595-633.

8. Delacroix, O.; Gaumont, A. C. Curr. Org. Chem. 2005, 9, 1851-1882. doi:10.2174/138527205774913079

9. Arbuzova, S. N.; Gusarova, N. K.; Trofimov, B. A. ARKIVOC 2006, No. v, 12-36. doi:10.3998/ark.5550190.0007.503

10. Honaker, M. T.; Hovland, J. M.; Salvatore, R. N. Curr. Org. Synth. 2007, 4, 31-45. doi:10.2174/157017907779981561

11. Beletskaya, I. P.; Ananikov, V. P.; Khemchyan, L. L. Synthesis of Phosphorus Compounds via Metal-Catalyzed Addition of $\mathrm{P}-\mathrm{H}$ Bond to Unsaturated Organic Molecules. In Phosphorus Compounds, Advanced Tools in Catalysis and Material Sciences; Peruzzini, M.; Gonsalvi, L., Eds.; Springer: Netherlands, 2011; Vol. 37, pp 213-264. doi:10.1007/978-90-481-3817-3_8

12. Koshti, V.; Gaikwad, S.; Chikkali, S. H. Coord. Chem. Rev. 2014, 265, 52-73. doi:10.1016/j.ccr.2014.01.006

13. Deprèle, S.; Montchamp, J.-L. J. Org. Chem. 2001, 66, 6745-6755. doi:10.1021/jo015876i

14. Leca, D.; Fensterbank, L.; Lacôte, E.; Malacria, M. Chem. Soc. Rev. 2005, 34, 858-865. doi:10.1039/B500511F

15. Oparina, L. A.; Gusarova, N. K.; Vysotskaya, O. V.; Artem'ev, A. V.; Kolyvanov, N. A.; Trofimov, B. A. Synthesis 2014, 46, 653-659. doi:10.1055/s-0033-1340497

16. Dombek, B. D. J. Org. Chem. 1978, 43, 3408-3409. doi:10.1021/jo00411a038

17. Routaboul, L.; Toulgoat, F.; Gatignol, J.; Lohier, J.-F.; Norah, B.; Delacroix, O.; Alayrac, C.; Taillefer, M.; Gaumont, A.-C. Chem. - Eur. J. 2013, 19, 8760-8764. doi:10.1002/chem.201301417

18. Bunlaksananusorn, T.; Knochel, P. Tetrahedron Lett. 2002, 43, 5817-5819. doi:10.1016/S0040-4039(02)01177-2

19. Fu, X.; Jiang, Z.; Tan, C.-H. Chem. Commun. 2007, 5058-5060. doi:10.1039/B713151H

20. Perrier, A.; Comte, V.; Moïse, C.; Richard, P.; Le Gendre, P. Eur. J. Org. Chem. 2010, 1562-1568. doi:10.1002/ejoc.200901407

21. Xu, Q.; Han, L.-B. J. Organomet. Chem. 2011, 696, 130-140. doi:10.1016/j.jorganchem.2010.08.043

22. Xu, Q.; Zhou, Y.-B.; Zhao, C.-Q.; Yin, S.-F.; Han, L.-B. Mini-Rev. Med. Chem. 2013, 13, 824-835. doi:10.2174/1389557511313060005

23. Tanaka, M. Top. Organomet. Chem. 2013, 43, 167-201. doi:10.1007/3418_2011_20 
24. Stockland, R. A., Jr.; Taylor, R. I.; Thompson, L. E.; Patel, P. B. Org. Lett. 2005, 7, 851-853. doi:10.1021/ol0474047

25. Lenker, H. K.; Richard, M. E.; Reese, K. P.; Carter, A. F.;

Zawisky, J. D.; Winter, E. F.; Bergeron, T. W.; Guydon, K. S.; Stockland, R. A., Jr. J. Org. Chem. 2012, 77, 1378-1385. doi:10.1021/jo202183u

26. Kawaguchi, S.; Nomoto, A.; Sonoda, M.; Ogawa, A. Tetrahedron Lett. 2009, 50, 624-626. doi:10.1016/j.tetlet.2008.11.079

27. Alonso, F.; Moglie, Y.; Radivoy, G.; Yus, M. Green Chem. 2012, 14, 2699-2702. doi:10.1039/C2GC35898K

28. Malysheva, S. F.; Gusarova, N. K.; Artem'ev, A. V.; Belogorlova, N. A.; Albanov, A. I.; Borodina, T. N.; Smirnov, V. I.; Trofimov, B. A. Eur. J. Org. Chem. 2014, 2516-2521. doi:10.1002/ejoc.201301786

29. Malysheva, S. F.; Gusarova, N. K.; Artem'ev, A. V.; Belogorlova, N. A.; Albanov, A. I.; Borodina, T. N.; Smirnov, V. I.; Trofimov, B. A. Synthesis 2014, 46, 2656-2662. doi:10.1055/s-0034-1378357

30. Hirai, T.; Han, L.-B. Org. Lett. 2007, 9, 53-55. doi:10.1021/ol062505।

31. Skene, W. G.; Belt, S. T.; Connolly, T. J.; Hahn, P.; Scaiano, J. C. Macromolecules 1998, 31, 9103-9105. doi:10.1021/ma9812229

\section{License and Terms}

This is an Open Access article under the terms of the Creative Commons Attribution License

(http://creativecommons.org/licenses/by/2.0), which permits unrestricted use, distribution, and reproduction in any medium, provided the original work is properly cited.

The license is subject to the Beilstein Journal of Organic Chemistry terms and conditions:

(http://www.beilstein-journals.org/bjoc)

The definitive version of this article is the electronic one which can be found at:

doi:10.3762/bjoc. 11.214 